\title{
Genetic diversity of related vibriophages isolated from marine environments around Florida and Hawaii, USA
}

\author{
C. A. Kellogg, J. B. Rose, S. C. Jiang, J. M. Thurmond, J. H. Paul* \\ Department of Marine Science, University of South Florida, 140 Seventh Ave. S., St. Petersburg, Florida 33701, USA
}

\begin{abstract}
Although viruses from the marine environment have been enumerated, isolated, and characterized, there is little information on the abundance or global distribution of specific phage types. To this end, we studied the abundance and distribution of phages which infect a marine bacterium isolated from Tampa Bay (Florida, USA), tentatively identified (Microbial ID, Inc., Newark, Delaware, USA) as Vibrio parahaemolyticus. Using this host, we have isolated over 60 phages from the Gulf of Mexico, Tampa Bay, Florida Keys, and Oahu, Hawaii (USA). These isolates are all Myoviridae, with head sizes ranging from $50 \pm 0.0$ to $65 \pm 4.2 \mathrm{~nm}$ and tail lengths of $60 \pm 3.6$ to $100 \pm 5.0 \mathrm{~nm}$. The type phage ( $\$ 16$ from Tampa Bay) has a double-stranded DNA genome of 51 to $58 \mathrm{~kb}$. A $1.5 \mathrm{~kb}$ EcoRI fragment of this genome has been cloned and used as a gene probe. All of the DNA from the phage isolates hybridized to this probe under stringent conditions, but not to DNA from other marine vibriophages and bacteriophages, suggesting genetic relatedness. Agarose gel electrophoresis of EcoRI digests of the DNAs, followed by Southern transfer and probing with the $1.5 \mathrm{~kb}$ gene probe, yielded 6 groups based upon banding patterns. These groups were not segregated geographically within the Florida isolates; however, all of the Hawaiian phages had a common restriction pattern. These data indicate that populations of genetically related phages are widely distributed over large geographic distances in the oceans.
\end{abstract}

KEY WORDS: Vibriophages · Bacteriophages - Biogeography · Diversity

\section{INTRODUCTION}

Attempts to classify bacteriophages into taxonomic groups, which could be arranged to infer phylogenetic relationships between viral groups, began over half a century ago (Burnet 1933). The advent of DNA technology has added criteria such as DNA-DNA homology, restriction endonuclease fragment patterns, and genomic DNA molecular weights (Werquin et al. 1988, Lindstrom \& Kaijalainen 1991) to the traditional diagnostics of size, morphology, serology, and physiological properties (Adams 1952). A combination of several of these methods, used to analyze eucaryotic algal viruses, led to the discovery of groups of viruses, from diverse locations, which share a common host and similar to identical morphologies, but have considerable

- Addressee for correspondence variability within their genomes (Schuster et al. 1986, Cottrell \& Suttle 1991). Recently, similar analysis was performed with 5 cyanophages which infect Synechococcus (Wilson et al. 1993). Limited homology under low stringency probing conditions did reveal a low level of relatedness among the 5 viruses isolated from the Sargasso Sea, Woods Hole Harbor (Massachusetts, USA), and the English Channel.

Other than the studies mentioned above, there has not been much research in the area of phylogeography of marine viruses, particularly phages. This dearth of information is especially surprising in its exclusion of vibriophages since this family (Vibrionaceae) contains the greatest number of reported phage-host systems for the marine environment (Moebus 1987), with the genus Vibrio comprising most of the hosts (Moebus \& Nattkemper 1981). Since the first isolation of a bacteriophage specific for Vibrio para- 
haemolyticus (Nakanishi et al. 1966), these phagehost systems have received much attention (Baross \& Liston 1968, Kaneko \& Colwell 1973. Sklarow et al. 1973, Baross et al. 1978a, b, Hidaka \& Tokushige 1978, Koga \& Kawata 1981, Koga et al. 1982). These studies, however, were largely concerned with the isolation, morphology, sensitivity to heat and chemicals, burst size, and host range of such phages. The objective of the research described herein was to conduct a systematic study with a large sample size that would determine the geographic distribution and genetic diversity of marine vibriophages that infect a host $V$. parahaemolyticus (strain 16), isolated from Tampa Bay, Florida, USA.

\section{MATERIALS AND METHODS}

Bacterial and viral strains. Host 16 (tentatively identified as Vibrio parahaemolyticus by Microbial ID, Inc., Newark, DE, USA) and its corresponding phage ( $\Phi 16)$ were isolated from surface waters at the St. Petersburg Pier in Tampa Bay in 1991. Host 16 was used to isolate all phages. The 9 bacteriophages with the prefix $\Phi \mathrm{KL}$ were isolated from near Key Largo in January, 1992 (Table 1, Fig. 1). Isolates with a $\Phi$ PEL prefix were col- lected during a cruise from Tampa Bay to the Dry Tortugas aboard the RV 'Pelican' during July 1992 (Table 1). The designations $\Phi M O A T, \Phi M A R Q$, and $\Phi K W H$ all refer to isolations from stations along a cruise track in the Florida Keys during June 1993 (Table 1, Fig. 1). Viruses from Mamala Bay, Hawaii, USA, are indicated by the $\Phi H$ prefix, with the rest of the letters indicating the station they were isolated from. $\Phi H A W I-1$ to $\Phi H A W I-10$ and $\Phi H D O-1$ and \$HDO-2 were all isolated in October 1993; the rest of the Hawaiian phages were isolated in February 1994 (Table 2, Fig. 2)

The host range of the phages was assayed by spotting $5 \mu$ l of lysate $\left[10^{10}\right.$ to $10^{11} \mathrm{pfu}$ (plaque forming units) $\mathrm{ml}^{-1}$ ] onto a lawn of bacteria. The host strains tested were Vibrio natrigens (DM1070), V. anguillarium (DM1107), Vibrio sp. (DI-9), V. parahaemolyticus (HER 1169), and V. parahaemolyticus (HER 1165). Both DM strains were isolated from lesioned fish from St. Johns River, FL (D. McGary \& D. Lim pers. comm.). DI-9 is a water column isolate found near Davis Island, FL (Jeffery et al. 1990). HER 1165 and 1169 were used by Koga et al. (1982) to isolate vibriophages from seawater around Japan. These 2 strains were obtained from the Felix d'Herelle Reference Center for Bacterial Viruses (Université Laval, Québec, Canada).

Table 1. Phages isolated in this study. Fl: Florida; HI: Hawaii

\begin{tabular}{|c|c|c|}
\hline Phages & Isolated from: & Date \\
\hline$\Phi 16$ & St. Petersburg Pier, Tampa Bay, FL & May 1991 \\
\hline ФKL3, ФKL5, ФKL6, ФKL7 & Canal, Key Largo, FL & January 1992 \\
\hline ФKL33, ФKL34, ФKL35, ФKL36 & Blackwater Sound, Key Largo, FL & January 1992 \\
\hline$\Phi \mathrm{KL} 44$ & Tarpon Sound, Key Largo, FL & January 1992 \\
\hline ФPEL1A-1, ФPEL1A-2 & Mouth of Tampa Bay, FL & July 1992 \\
\hline ФPEL8A-1, ФPEL8A-2, ФPEL8A-3 & Gulf of Mexico, Stn 8, Surface waters & July 1992 \\
\hline ФPEL8C-1, ФPEL8C-2 & Gulf of Mexico, Stn 8, $1500 \mathrm{~m}$ & July 1992 \\
\hline ФPEL13A-1 & Off Garden Cay, Dry Tortugas, FL & July 1992 \\
\hline $\begin{array}{l}\text { ФPEL13B-1, ФPEL13B-2, ФPEL13B-3, ФPEL13B-4, } \\
\text { ФPEL13B-5, ФPEL13B-6, ФPEL13B-7, ФPEL13B-8, } \\
\text { ФPEL13B-9, ФPEL13B-10 }\end{array}$ & Moat, Ft. Jefferson, Dry Tortugas, FL & July 1992 \\
\hline ФМOAT-1 & Moat, Ft. Jefferson, Dry Tortugas, FL & June 1993 \\
\hline ФMARQ-1, ФMARQ-2, ФMARQ-3 & Marquesas, FL & June 1993 \\
\hline ФKWH-2, ФKWH-3, ФKWH-4 & Key West Harbor, FL & June 1993 \\
\hline $\begin{array}{l}\text { ФHAWL-1, ФHAWI-2, ФHAWI-3, ФHAWI-4, } \\
\text { ФHAWI-5, ФHAWI-6, ФHAWI-7, ФHAWI-8, } \\
\text { ФHAWI-9, ФHAWI-10 }\end{array}$ & Ala Wai Canal, Honolulu, $\mathrm{Hl}$ & October 1993 \\
\hline ФHDO- $1, \Phi H D 0-2$ & Ke'ehi Lagoon, HI & October 1993 \\
\hline ФHD0-3, ФHD0-4, ФHD0-5, ФHD0-6 & Ke'ehi Lagoon, HI & February 1994 \\
\hline$\Phi H D 1 S-1, \Phi H D 1 S-2$ & Sand Island Transect, HI & February 1994 \\
\hline$\Phi H D 2 S-1, \Phi H D 2 S-2, \Phi H D 2 S-3$, HD2S-4, ФHD2S-5 & Sand Island Outfall, HI & February 1994 \\
\hline$\Phi H C 1-1, \Phi H C 1-2, \Phi H C 1-3, \Phi H C 1-4$ & Upper Pearl Harbor, HI & February 1994 \\
\hline$\Phi H C 2-1, \Phi H C 2-2, \Phi H C 2-3, \Phi H C 2-4$ & Mid Pearl Harbor, $\mathrm{HI}$ & February 1994 \\
\hline$\Phi H C 3-1, \Phi H C 3-2, \Phi H C 3-3$ & Mouth of Pearl Harbor, $\mathrm{HI}$ & February 1994 \\
\hline
\end{tabular}


tubes contained $2 \mathrm{ml}$ of $1 \%$ agar, $1 \mathrm{ml}$ of Host 16, and $100 \mu \mathrm{l}(0.1 \mathrm{ml})$ of the phage-Tris suspension. Dilutions of $10^{-2}, 10^{-4}, 10^{-6}$, and $10^{-8}$ of these suspensions were also overlaid, with replicates. After an overnight incubation, a single plaque would be picked as before, and the procedure would be repeated. From these plates, the phages were eluted to make a lysate.

Lysate production. To each agar plate (12 to 14 plates total), $5 \mathrm{ml}$ of $0.5 \mathrm{M}$ Tris ( $\mathrm{pH}$ 8) was added and allowed to remain at room temperature for $15 \mathrm{~min}$. For each isolate, the lysate was removed from the plates into oakridge tubes with a sterile $10 \mathrm{ml}$ syringe. The lysates were centrifuged at $8000 \mathrm{rpm}, 4989 \times \mathrm{g}$, for 10 min to pellet any agar or cellular debris. The supernatants were then filtered through an ultra low binding cellulose acetate $0.2 \mu \mathrm{m}$ sterile filter (Costar, Cambridge, MA) and stored at $4^{\circ} \mathrm{C}$

DNA extraction. The ultracentrifugation method of Sambrook et al. (1989) was followed except that $30 \mu \mathrm{g}$ $\mathrm{ml}^{-1}$ DNAase and $5 \mu \mathrm{g} \mathrm{ml}{ }^{-1}$ RNAase were used, and the bacteriophage particles were collected by ultracentrifugation $\left(70000 \mathrm{rpm}, 265070 \times \mathrm{g}, 4^{\circ} \mathrm{C}, 90 \mathrm{~min}\right)$. DNA was collected by ethanol precipitation.

Radiolabeled probe. A 1.5 kb EcoRI digestion fragment of the $\$ 16$ genome was randomly cloned into the Riboprobe vector pGEM3Z using standard cloning techniques (Maniatis et al. 1982). There is some evidence, based on preliminary translation studies, that it is a gene. $\mathrm{A}^{35} \mathrm{~S}$ RNA probe was prepared by transcription of the fragment with T7 RNA polymerase, using ${ }^{35}$ S UTP (Church \& Gilbert 1984, Frischer et al. 1990).

Dot blot analysis. Each of the phage DNAs was dotted onto charged nylon membranes (Zetaprobe; BioRad, Richmond, CA, USA) in concentrations of 0.1 and $0.05 \mu \mathrm{g}$. The $\Phi 16$ DNA was a positive control; negative controls included Host 16 chromosomal DNA, T2 phage DNA, and salmon sperm DNA. The filter was baked in a vacuum oven for $2 \mathrm{~h}$ at $80^{\circ} \mathrm{C}$, then hybridized overnight with the $1.5 \mathrm{~kb}$ fragment at $42^{\circ} \mathrm{C}$ as previously described (Church \& Gilbert 1984, Frischer et al. 1990). Filter washing consisted of 1 wash in $2 \times \mathrm{SSC}[0.3 \mathrm{M} \mathrm{NaCl}, 0.03 \mathrm{M}$ sodium citrate ( $\mathrm{pH} 7.0$ ) containing $1 \mathrm{mM}$ dithiothreitol] for $5 \mathrm{~min}$ at room temperature, followed by three $60 \mathrm{~min}$ washes at $65^{\circ} \mathrm{C}$ in PSE $[0.25 \mathrm{M}$ sodium phosphate, $2 \%$ sodium dodecyl sulfate, $1 \mathrm{mM}$ EDTA (pH 7.4)], and three $30 \mathrm{~min}$ washes in PES $[40 \mathrm{mM}$ sodium phosphate, $1 \%$ SDS, $1 \mathrm{mM}$ EDTA $\left(\mathrm{pH} \mathrm{7.4)]} \mathrm{at} 65^{\circ} \mathrm{C}\right.$. Filters were dried briefly under a heat lamp, and hybridization was detected by autoradiography.

Restriction fragment analysis. Restriction endonuclease digestions of various phage isolates were performed using EcoRI, DpnI, and AvaI (IBI, New Haven, CT, USA), and $\Phi 16$ was additionally digested with
BamHI, HindIII, KpnI, PstI, SalI, BglII, ClaI, SphI, XbaI, HpaI, and EcoRV (Promega, Madison, WI, USA). The DNA was digested in $20 \mu$ lotal volume containing $1 \mu \mathrm{g}$ of DNA, the appropriate buffer and enzyme (as recommended by the manufacturers), and sterile deionized water to make up the difference. Digestions proceeded overnight at $37^{\circ} \mathrm{C}$, followed by agarose gel electrophoresis with $10 \times$ TAE buffer and Hoechst 33258 stain (DeFlaun \& Paul 1986). The DNA was then transferred to a charged nylon membrane (Zetaprobe; BioRad) by Southern blotting and probed as described above.

Electron microscopy. Viral lysates were diluted 1:10 in deionized water. A total of $1 \mu \mathrm{l}$ of each dilute lysate was dotted onto a 300 mesh Formvar-coated copper grid (Electron Microscopy Sciences, Fort Washington, PA, USA), and allowed to air dry. The grids were then stained with $2 \%$ uranyl sulfate (Polysciences, Warrington, PA). Photography was performed at a magnification of $\times 60000$. Size estimates were made from the electron micrograph negatives, dividing by the magnification at which they were taken. The accuracy of the magnification was checked with $50 \mathrm{~nm}$ Nanosphere size standards (Electron Microscopy Sciences).

\section{RESULTS}

\section{Phage distribution}

The original phage-host system of $\Phi 16$-Vibrio parahaemolyticus 16 was isolated from a vortex flow filtration retentate of Tampa Bay water in 1991 (Table 1. Fig. 1). During subsequent cruises to Key Largo, the Gulf of Mexico, Dry Tortugas, and Mamala Bay, additional bacteriophages were isolated on Host 16. Of the Key Largo phages, 4 (ФKL33, ФKL34, ФKL35, and ФKL36) were isolated from a sponge, while the rest were found in VFF retentates. In July 1992, 2 more phages were isolated from the mouth of Tampa Bay (ФPEL1A-1, ФPEL1A-2). At Stn 8 of a transect into the Gulf of Mexico, 5 phages were isolated; 3 from the surface waters ( $\Phi P E L 8 A-1,-2$, and -3), and 2 from a depth of $1500 \mathrm{~m}$ ( $\Phi P E L 8 C-1$ and -2). One virus (ФPEL13A-1) was isolated from the water column near Garden Key in the Dry Tortugas. Fort Jefferson, on Garden Key, has a shallow moat of salt water, and it was from there that the remaining 10 QPEL phages ( PPEL13B-1 to -10) were obtained. In June 1993, we returned to the moat at Fort Jefferson and isolated DMOAT-1. During the same sampling trip the following isolations were also made: $\Phi M A R Q-1$ to -3 from the Marquesas and ФKWH-2 to -4 from Key West Harbor. During October 1993, 10 bacteriophages were isolated from the Ala Wai Canal in Honolulu, HI (ФHAWI-1 to -10 ), and 2 
from the Ke'ehi Lagoon ( $\mathscr{H} \mathrm{HDO}-1$ and -2). The next Hawailan trip was in February 1994 and resulted in isolations from the Ke'ehi Lagoon ( $\Phi \mathrm{HDO}-3$ to -6 ), the Sand Island Outfall ( $\Phi$ HD1S-1, ФHD1S-2, and $\Phi$ HD2S1 to -5 ), and Pearl Harbor ( $\Phi H C 1-1$ to $-4, \Phi H C 2-1$ to -4 , and $\Phi \mathrm{HC}-1$ to -3$)$. The total number of isolates described here is 67,33 of which are from the Gulf of Mexico and waters surrounding Florida and 34 of which are from Mamala Bay, Oahu, Hawaii (Táble 1, Figs. $1 \& 2$ ).

Detectable concentrations of these phages, determined from plaque titers and calculated for the original seawater, range from 3 pfu $\mathrm{l}^{-1}$ (Pearl Harbor) to $1.94 \times$ $10^{3}$ pfu $1^{-1}$ (Ft. Jefferson Moat, Dry Tortugas). The average concentration around Key Largo is on the order of $10^{2}$ pfu $\mathrm{l}^{-1}$, while concentrations around Hawaii are a magnitude lower (Table 2). These calculations assume $100 \%$ concentration efficiency. Previous experiments (Paul et al. 1991, Jiang et al. 1992) have shown that VFF concentration with a $100 \mathrm{kDa}$ membrane has an average efficiency slightly above $80 \%$, making these phage concentrations conservative.

\section{Phage characteristics}

Using all 67 bacteriophages, 5 alternate hosts (see 'Materials and methods') were tested for sensitivity. None of these viruses plaqued on any host other than Host 16.

All of the phages examined by transmission electron microscopy had similar morphologies (Fig. 3). They were all Myoviruses (Bradley Group A), having icosahedral heads and long, contractile tails. The head diameters ranged from 50 to $65 \mathrm{~nm}$ and the tail lengths from 60 to $100 \mathrm{~nm}$.

The molecular weight of the $\Phi 16$ genome was calculated to be approximately $58 \mathrm{~kb}$ by addition of HpaI fragments. This is larger than the EcoRI fragment total (51 kb), presumably due to co-migration of similar sized fragments in the latter digests. For the same reason, the $58 \mathrm{~kb}$ may still underestimate the genome size, but that is not believed likely since digestion by the other restriction enzymes tested (AvaI, BamHI, HindIII, KpnI, PstI, DpnI, SalI, BgliI, ClaI, SphI, XbaI, EcoRV) has not resulted in a higher molecular weight.

DNA from $\Phi 16$ and the $9 \Phi K L$ was digested with DpnI and found to be very susceptible to this enzyme. Gel electrophoresis, as well as autoradiography with the $1.5 \mathrm{~kb}$ probe, revealed more than 20 restriction fragments in all cases. These fragments ranged in size from around $6.5 \mathrm{~kb}$ down to less than $0.12 \mathrm{~kb}$.

On the dot blots, DNA from 58 of the 67 bacteriophages is shown to hybridize strongly with the $1.5 \mathrm{~kb}$ fragment cloned from the $\Phi 16$ genome (Fig. 4). The 11
Table 3. Groupings of phage isolates based upon similar EcoRI restriction banding patterns detected by autoradiography after probing with the $\$ 16$ gene probe

\begin{tabular}{|c|c|c|c|}
\hline $\begin{array}{l}\text { Super } \\
\text { group }\end{array}$ & Phages & $\begin{array}{l}\text { Visible } \\
\text { bands" }\end{array}$ & $\begin{array}{c}\text { Molecular } \\
\text { weights (kb) }\end{array}$ \\
\hline A & $\Phi 16$ & 1 & 1.5 \\
\hline $\mathrm{B}$ & $\begin{array}{l}34 \text { Hawail phages, } \\
\text { \$KL33 }\end{array}$ & 2 & $4.0,1.5$ \\
\hline C & $\begin{array}{l}\text { ФKL3, ФKL5, ФKL44, } \\
\text { ФKL7, ФKL34, ФKL6, } \\
\text { ФPEL13A-1, ФPEL1A-1, } \\
\text { ФPEL8C-2, ФPEL8A-1, } \\
\text { ФMARQ-1, ФKWH-2, } \\
\text { ФKWH-3, ФKWH-4 }\end{array}$ & 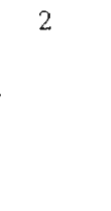 & $8.0,4.0$ \\
\hline $\mathrm{D}$ & ФPEL8A-3, ФPEL8C-1 & 3 & $8.0,4.0,2.0$ \\
\hline$E$ & $\begin{array}{l}\text { ФKL36, ФPEL 1A-2, } \\
\text { ФPEL8A-2, } \\
\text { ФPEL13B-1 to }-5 \\
\text { ФPEL13B-7 to }-10 \\
\text { ФMOAT-1 }\end{array}$ & 1 & 4.0 \\
\hline $\mathrm{F}$ & ФKL35, ФPEL13B-6 & 1 & 4.2 \\
\hline
\end{tabular}

phage DNAs not included on the dot blots, $\Phi$ HAWI-1, ФHD2S-4, ФHC2-4, ФHC3-3, ФMOAT-1, ФMARQ-1 to -3 , and $\Phi K W H-2$ to -4 , have been visualized with the probe on autoradiograms of Southern transfers. None of the negative controls hybridized.

EcoRI digests of the vibriophages were difficult to visualize on $1.0 \%$ agarose gels by UV transillumination since many of the bands are small or faint. Southern transfers of these digests, which were then probed with the $1.5 \mathrm{~kb}$ probe, yielded autoradiograms which were much more easily compared. The patterns observed on the autoradiograms allowed the phages to be grouped (Table 3, Fig. 5). Thus far, 6 groups have been identified. This arrangement includes a group containing only $\Phi 16$, a group containing all 34 Hawaiian phages, and 4 other groups comprised of a mixture of the remaining Key Largo, Gulf of Mexico, and Dry Tortugas isolates.

\section{DISCUSSION}

Over 60 phages have been isolated with Host 16 from various marine environments over a geographic distance of more than 4500 miles. In addition to sharing a common host, and being morphologically similar, these viruses are likely genetically related, as shown by the stringent hybridization of their DNAs with a $1.5 \mathrm{~kb}$ gene probe made from an EcoRI digest of $\Phi 16$ DNA. 

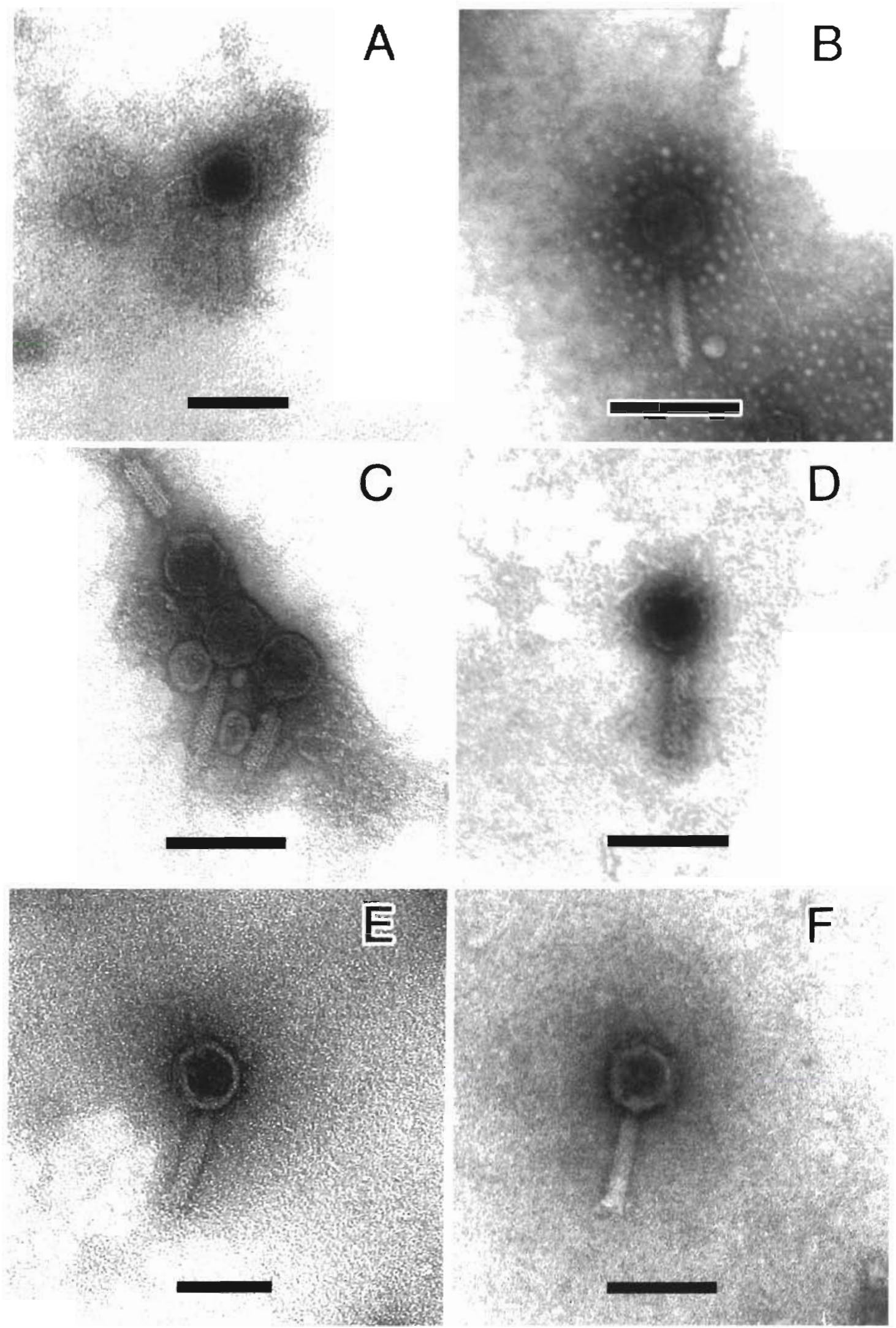

Fig 3 Electron photomicrographs of selected vibrophages A. Ф16; B. ФPEL1A-1 C. ФPEL13B-2; D: ФHC1.-4; E: ФKL3; F: ФKL33 

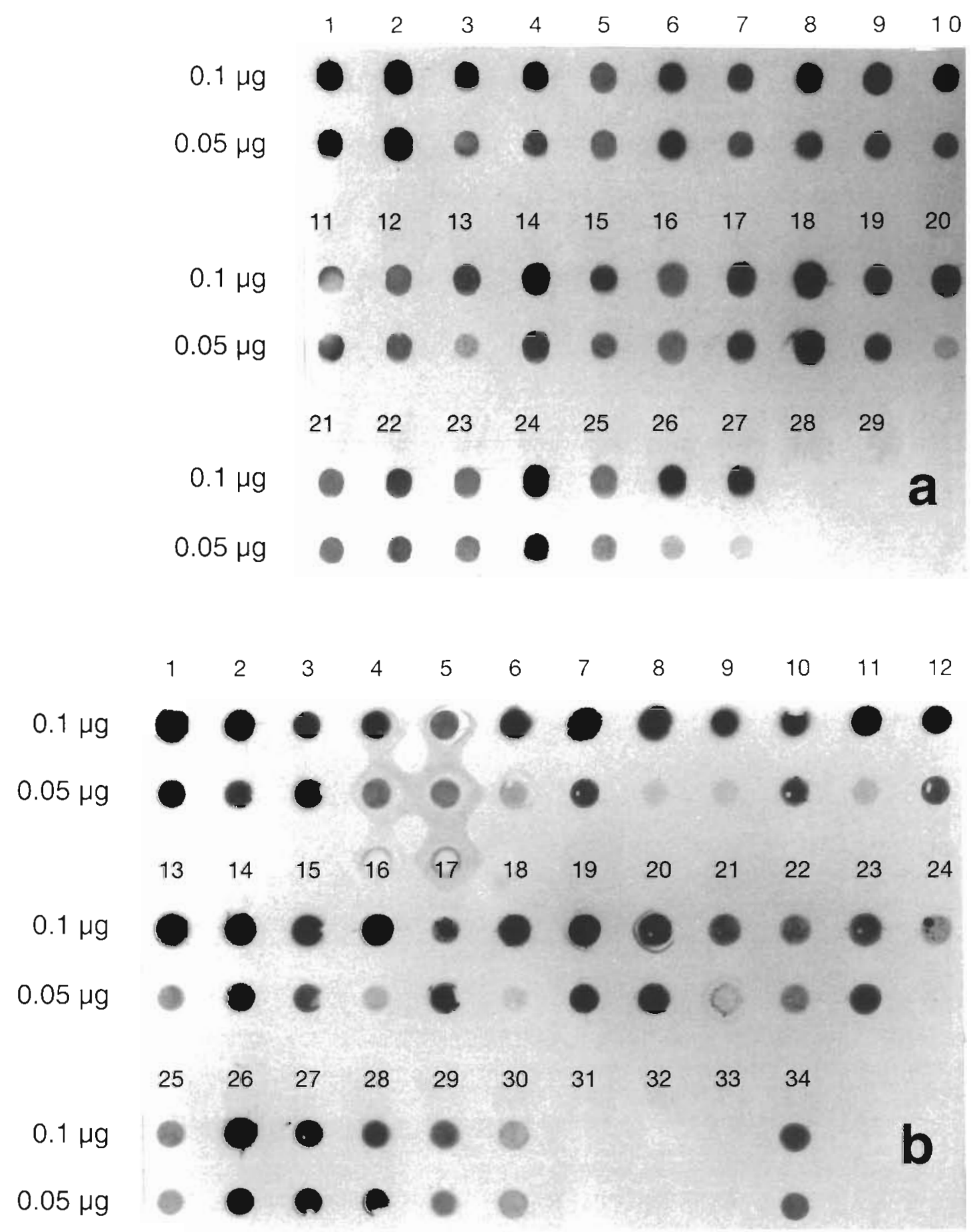

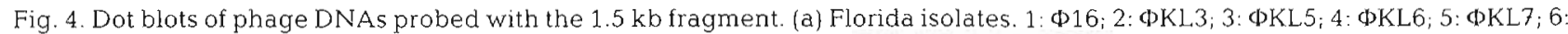
ФKL33; 7: ФKL34; 8: ФKL35; 9: ФKL36; 10: ФKL44; 11: ФPEL13B-1; 12: ФPEL 13B-2; 13: ФPEL13B-3; 14: ФPEL13B-4; 15: ФPEL13B-5; 16: ФPEL13B-6; 17: ФPEL13B-7; 18: ФPEL13B-8; 19: ФPEL13B-9; 20: ФPEL13B-10; 21: ФPEL1A-1; 22: ФPEL1A-2; 23: ФPEL8A-1; 24: ФPEL8A-2; 25: ФPEL8A-3; 26: (DPEL8C-1; 27: ФPEL8C-2; 28: Host 16 chromosomal DNA; 29: ФT2. (b) Hawailan isolates. 1: ФHAWI2; 2: ФHAWI-3; 3: ФHAWI-4; 4: ФHAWI-5; 5: ФHAWI-6; 6: ФHAWI-7; 7: ФHAWI-8; 8: ФHAWI-9; 9: ФHAWI-10; 10: ФHD0-1; 11:

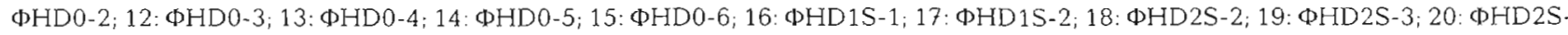
4; 21: ФHD2S-5; 22: ФHC1-1; 23: ФHC1-2; 24: ФHC1-3; 25: ФHC1-4; 26; ФHC2-1; 27: ФHC2-2; 28: ФHC2-3; 29; ФHC3-1; 30: ФHC32; 31: Host 16 chromosomal DNA; 32: ФHSIC-3; 33: salmon sperm DNA; 34: Ф16 

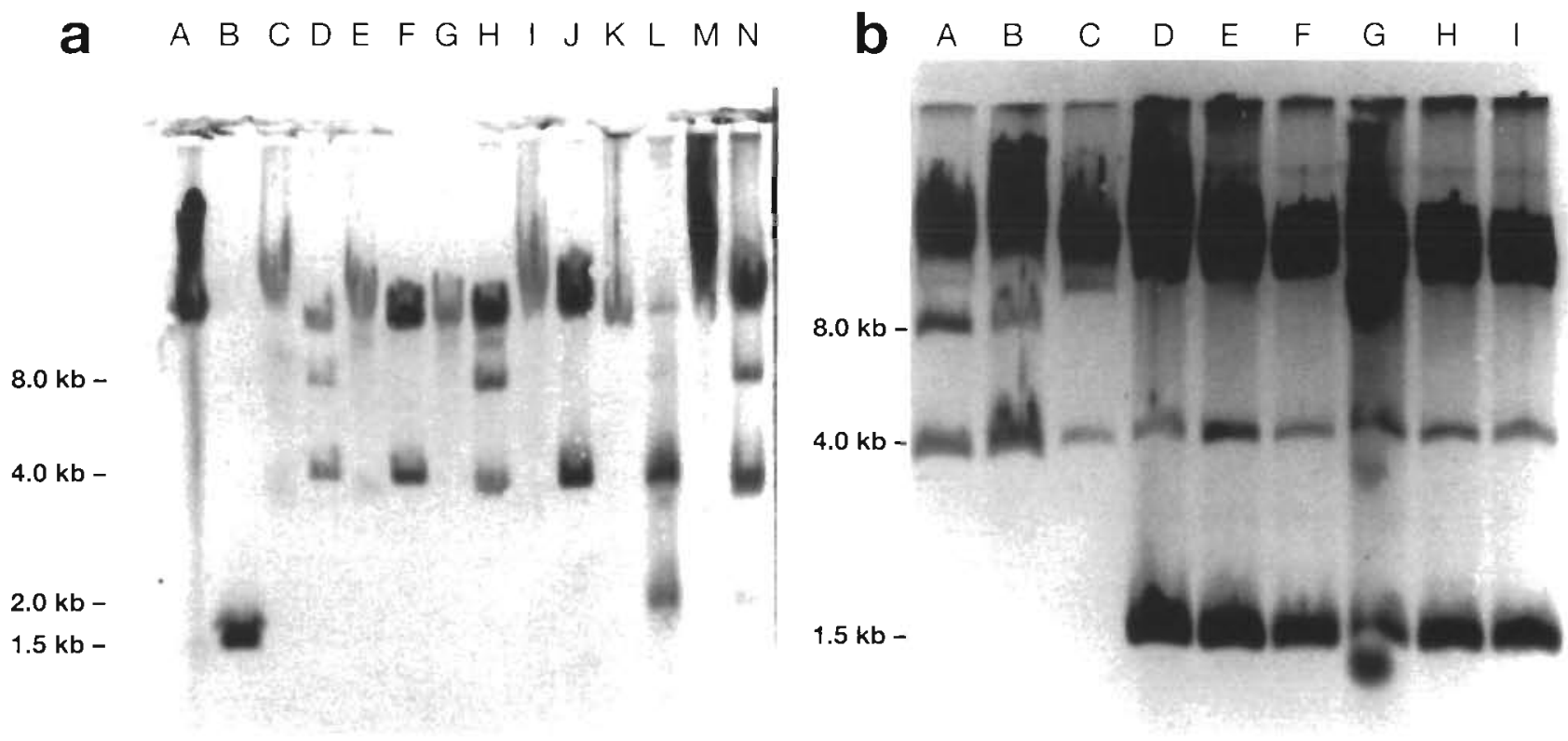

Fig. 5. Autoradiograms of EcoRI digested phage DNAs which have been probed with the $1.5 \mathrm{~kb}$ fragment. (a) A: uncut $\Phi 16$; B: digested $\Phi 16$; C: uncut $\Phi P E L 1 A-1 ;$ : digested $\Phi P E L 1 A-1 ; E$ : uncut $\Phi P E L 1 A-2 ; F$ : digested $\Phi P E L 1 A-2 ;$ G: Uncut $\Phi P E L 8 A-1$; $\mathrm{H}$ : digested ФPEL8A-1; I: uncut ФPEL8A-2; J: digested ФPEL8A-2; K: uncut ФPEL8A-3; L: digested ФPEL8A-3; M: uncut ФPEL8C-1; N: digested $\Phi$ PEL8C-1, (b) All EcoR1 digests, no uncut DNAs: A: ФKL7; B: ФPEL8C-1; C: ФPEL13B-1; D: $\$$ HAWI-10; E: $\Phi H D 0-1 ; F:$ : $H D 1 S-1 ;(i:$ DHD2S-1; H: $\Phi H C 1-2$; : $\Phi H C 2-3$. Note that the $2.0 \mathrm{~kb}$ band of $\Phi P E L 8 C-1$ is not visible in this film due to incomplete digestion of that sample

No other host examined was sensitive to any of these phages. Although a limited number of strains were examined, other research has shown that some Vibrio parahaemolyticus phages are highly specific, giving no lytic response on 53 V. parahaemolyticus strains and 95 other Vibrio strains (Sklarow et al. 1973)

Since viruses are by definition obligate cellular parasites, they must remain in close proximity to their chosen host if they are to survive for any period of time in any marine environment. The detection and isolation of these phages suggests they are being actively reproduced, since marine bacteriophages have been found to decay rapidly once outside of their hosts (Heldal \& Bratbak 1991). Because of the specificity of phage-host systems in the marine environment, it has previously been stated that the distribution of the host bacterium can be mapped by the distribution of its phages (Borsheim 1993) For this reason, we have not done any additional experiments to determine the distribution of Host 16.

The fact that DpnI, an enzyme specific for DAMmethylation sites, produced many $(20+)$ restriction fragments indicates extensive methylation of these phages' genomes. This is one of several bacteriophage defense adaptations to avoid host restriction systems.

Similar size, identical morphology, and a common host were the first indicators of possible relatedness between these phages. The primary confirming evidence was homology to the $1.5 \mathrm{~kb}$ gene probe which was found to be present in all of these geographically diverse bacteriophages. The phage groups are nonidentical, as evidenced by their differing restriction patterns and autoradiography patterns, yet clearly share sequence homology of at least $1.5 \mathrm{~kb}(\geq 2.6 \%$ of the genome). While it is possible that these related bacteriophages stem from a common ancestral Vibriophage, there is not enough information to be certain. Without knowing what function the common gene serves, it is not possible to be sure it is not a gene (or part of a gene) which is common to these viruses due to convergent evolution or horizontal gene transfer (Haggard-Ljungquist et al. 1992) rather than derivation from a common ancestor. The $1.5 \mathrm{~kb}$ gene probe has not hybridized with DNA from any other viral group (namely T2, and several other environmental isolates), which rules out a 'trans-species' function, such as DNA polymerase. It also does not hybridize with DNA from $V p 1, V p 5, V p 6, V p 11$, or $V p 12$, which are marine phages specitic to Vibrio parahaemolyticus strains HER1165 and HER1169. This suggests the DNA is specific to this group of vibriophages.

The rationale of screening the viral isolates by probing EcoRI digests with this $1.5 \mathrm{~kb}$ fragment was to quickly sort the phages into groups. The $1.5 \mathrm{~kb}$ common region from a representative of each group could then be PCR amplified, cloned, and then sequenced. A comparison of these sequences would allow an estimate of genetic divergence between the 'genotypes' to 
be calculated from the similarities of their DNA sequences.

In light of the evidence that phage-host systems can reflect different water masses (Hidaka \& Sakita 1981, Moebus \& Nattkemper 1981, Moebus 1983, Hidaka et al. 1987), we have speculated that the distribution of these vibriophages in the Gulf of Mexico and around the Florida peninsula may be related to the path of the Florida Current, which curves around the state before heading north to form the Gulf Stream. While there is clearly no sequential geographic distribution of the restriction banding pattern groups, advection by the Florida Current could explain how Group E phages can be found in Key Largo, Tampa Bay, offshore in the Gulf of Mexico, and in the Fort Jefferson moat in the Dry Tortugas.

A mechanism of long-distance transport other than natural currents exists in the form of cargo ships and freighters which cross the Panama Canal. Such vessels often take on seawater as ballast, and the local microbial and planktonic populations are unnoticed passengers (Hallegraeff \& Bolch 1992, McCarthy \& Khambaty 1994). Mamala Bay and Tampa Bay are both ports of call for these types of ships, and ships en route to Miami or further east would have to go around the Dry Tortugas, Marquesas, and Florida Keys on their way out of the Gulf of Mexico.

Hidaka (1980) found a Vibrio sp. phage-host system with a fairly wide oceanic distribution: the host was isolated near Hawail, but the phage was found in waters just south of Japan. This study corroborates that such 'long-distance' phage-host systems may not be uncommon. The research in this paper confirms that there are identifiable genetic populations of the $\mathbf{\Phi 1 6 -}$ type vibriophages not only in the Gulf of Mexico, Tampa Bay, and Florida Keys, but also around Hawaii, some 4500 miles distant. This suggests that virus 'species' such as these vibriophages may be widely distributed in the global ocean.

Acknowledgements. We appreciate the unwavering patience of Dr Peter Steele, Pathology Dept, All Children's Hospital, as well as the use of the department's TEM. Thanks to Dr Hans W. Ackermann for his help in obtaining strains HER1165 and HER 169. This research was supported by NSF grant number OCE-9115942, a grant from the Mamala Bay Study Commission, and an Institute for Biomolecular Sciences Summer Fellowship (C.A.K.).

\section{LITERATURE CITED}

Adams, M. H. (1952). Classification of bacterial viruses: characteristics of the $\mathrm{T} 5$ species and of the T2, C16 species. J. Bacteriol. 64: 387-396

Baross, J. A., Liston, J. (1968). Isolation of Vibrio parahaemolyticus from the Northwest Pacific. Nature 217: $1263-1264$
Baross, J. A., Liston, J., Morita, R. Y (1978a). Incidence of Vibrio parahaemolyticus bacteriophages and other Vibrio bacteriophages in marine samples. Appl environ. Microbiol. 36: 492-499

Baross, J. A.. Liston, J., Morita, R. Y (1978b). Ecological relationship between Vibrio parahaemolyticus and agardigestıng vibrios as evidenced by bacteriophage susceptibility patterns. Appl. environ. Microbiol. 36: 500-505

Borsheim, K. Y (1993). Native marne bacteriophages. FEMS Microbiol. Ecol. 102: 141-159

Burnet, F. M. (1933). The classification of dysentery-coli phages IIr. Correlation of serological classification with certain biochemical tests. J. Path. Bact. 37: 179-184

Church, G. M., Gilbert, W. (1984). Genomic sequencing. Proc. natl Acad. Sci. U.S.A. 81: 1991-1995

Cottrell, M. T., Suttle, C. A. (1991). Wide-spread occurrence and clonal variation in viruses which cause lysis of a cosmopolitan eukaryotic marine phytoplankter, Micromonas pusilla. Mar. Ecol. Prog. Ser 78: 1-9

DeFlaun, M. F., Paul, J. H. (1986). Hoechst 33258 staining of DNA in agarose gel electrophoresis. J. Microbiol. Meth. 5: 265-270

Frischer, M. E., Thrumond, J. M., Paul, J. H. (1990). Natural plasmid transformation in a high-frequency-of-transformation marine Vibrio strain. Appl. environ. Microbiol. 56: $3439-3444$

Haggard-Ljungquist, E., Hallıng, C., Calendar, R. (1992). DNA sequences of the tail fiber genes of bacteriophage P2: evidence for horizontal transfer of tail fiber genes among unrelated bactenophages. J. Bacteriol. 174 : $1462-1477$

Hallegraeff, G. M., Bolch, C. J. (1992). Transport of diatom and dinoflagellate resting spores in ships' ballast water: implications for plankton biogeography and aquaculture. J. Plankton Res. 14: 1067-1084

Heldal, M., Bratbak, G. (1991). Production and decay of viruses in aquatic environments. Mar. Ecol. Prog. Ser 72 : $205-212$

Hidaka, T (1980). Analytical research of microbial ecosystems in seawater around fishing ground - II. On a residentary bacteriophage-system in seawater around the Ryuku Island Arc Mem. Fac. Fish., Kagoshima Univ. 29: $327-337$

Hidaka, T. Kamino, Y., Kawabe, T (1987). On phage-sensitive bacteria in seawater of Kagoshima Bay. Mem. Fac. Fish. Kagoshima Univ. 36: 17-25

Hidaka, T., Sakita, I. (1981). Analytical research of microbial ecosystems in seawater around fishing ground - II. On the habitat segregation of bacteriophage systems in the west region of the northern Ryuku Island Arch. Mem. Fac. Fish. Kagoshima Univ. 30: 331-338

Hidaka, T., Tokushige, A. (1978). Isolation and characterization of Vibrio parahaemolyticus bacteriophages in seawater. Mem. Fac. Fish. Kagoshima Univ. 27: 79-90

Jeffrey, W. H., Paul, J. H., Stewart, G. J. (1990). Natural transformation of a marine Vibrio species by plasmid DNA. Microb. Ecol. 19: 259-268

Jiang, S. C., Thurmond, J. M., Pichard, S. L., Paul, J. H. (1992) Concentration of microbial populations from aquatic environments by vortex flow filtration. Mar. Ecol. Prog. Ser. 80 $101-107$

Kaneko, T., Colwell, R. R. (1973). Ecology of Vibrio parahaemolyticus in the Chesapeake Bay. J. Bacteriol. 113. $24-32$

Koga, T., Kawata, T (1981). Structure of a novel bacteriophage VP3 for Vibrio parahaemolyticus. Microbiol. Immunol. 25: 737-740 
Koga, T., Toyoshima, S., Kawata, T (1982). Morphological varieties and host ranges of Vibrio parahaemolyticus bacteriophages isolated from seawater. Appl. environ. Microbiol. $44: 466-470$

Lindstom, K., Kaijalainen, S. (1991). Genetic relatedness of bacteriophage infecting Rhizobium galegae strains. FEMS Lett. 82: $241-246$

Maniatis, T., Fritsch, E. F., Sambrook, J. (1982). Molecular cloning: a laboratory manual. Cold Spring Harbor Laboratory, Cold Spring Harbor, NY

McCarthy, S. A., Khambaty, F. M. (1994). International dissemination of epidemic Vibrio cholerae by cargo ship ballast and other nonpotable waters. Appl. environ. Microbiol. 60: $2597-2601$

Moebus. K. (1983). Lytic inhibition responses to bacteriophages among marine bacteria, with special reference to the origin of phage-host systems. Helgoländer Meeresunters. 36: 375-391

Moebus, K. (1987). Ecology of marine bacteriophages. In: Goyal, S. M., Gerba, C. P., Bitton, G. (eds.) Phage ecology. John Wiley \& Sons, New York, p. 137-156

Moebus, K., Nattkemper, H. (1981). Bacteriophage sensitivity patterns among bacteria isolated from marine waters. Helgoländer Meeresunters. 34: 375-385

Nakanishi, H., Iida, Y., Maeshima, K., Teramoto, T., Hosaka, Y., Ozaki, M. (1966). Isolation and properties of bacteriophages of Vibrio parahaemolyticus. Biken J. 9: 149-157

Paul, J. H. (1982). Use of Hoechst dyes 33258 and 33342 for

This article was presented by S. Y Newell (Senior Editorial Advisor), Sapelo Island, Georgia, USA enumeration of attached and planktonic bacteria. Appl environ. Microbiol. 43: 939-944

Paul, J. H., Jiang, S. C., Rose, J B. (1991). Concentration of viruses and dissolved DNA from aquatic environments by vortex flow filtration. Appl. environ. Microbiol. 57: $2197-2204$

Paul, J. H., Rose, J. B., Jiang, S. C., Kellogg, C. A., Dickson, L. (1993). Distribution of viral abundance in the reef environment of Key Largo, Florida. Appl. environ. Microbiol. 59: $718-724$

Sambrook, J., Fritsch, E. F., Maniatis, T. (1989). Molecular cloning: a laboratory manual, 2nd edn. Cold Spring Harbor Laboratory Press, Cold Spring Harbor, NY

Schuster, A. M., Burbank, D. E., Meister, B., Skrdla, M. P. Meints, R. H., Hattman, S., Swinton, D, Van Etten, J. L. (1986). Characterization of viruses infecting a eukaryotic Chlorella-like green alga. Virology 150: 170-1.77

Sklarow, S. S., Colwell, R. R., Chapman, G. B., Zane, S. F. (1973). Characteristics of a Vibrio parahaemolyticus bacteriophage isolated from Atlantic coast sediment. Can. J. Microbiol. 19: 1519-1520

Werquin, M., Ackermann, H.-W., Levesque, R. (1988). A study of 33 bacteriophages of Rhizobium meliloti. Appl. environ. Microbiol. 54: 188-196

Wilson, W. H., Joint, I. R., Carr, N. G., Mann, N. H. (1993). Isolation and molecular characterization of five marine cyanophages propagated on Synechococcus sp. strain WH7803. Appl environ. Microbiol. 59: 3736-3743

Manuscript first received: September 19, 1994

Revised version accepted: December 19, 1994 